\title{
PATRISTIC AND NEOPATRISTIC THEOLOGY? PERIODS OF PATROLOGY IN THE CHURCH LIFE
}

\author{
Prof. Ph.D. Ion Marian CROITORU, \\ Faculty of Theology and Sciences of Education, \\ Valahia University of Târgoviște, \\ ROMANIA \\ E-mail: ioncroitoru@yahoo.fr
}

\begin{abstract}
Many debates take place around the concepts of patristic theology and neopatristic theology, and also concerning the syntagms neopatristic or new patristic synthesis, all of them having as a substratum the issue of accepting or not limits for the patristic period. To avoid the netting of a lay science, Patrology has a permanent theological character and has no limits in history, just as the Holy Tradition of the Church is without limits. This fact is due to the situation that the Holy Fathers are not just authentic bearers of the Holy Tradition, but also its creators, in the sense of dynamic continuers of the spiritual and dogmatic heritage of the one, holy, catholic and apostolic Church. Accepting a terminus point for the patristic period would trigger many consequences, such as doubting the work and the presence of the Holy Spirit in the Church, ranking, in a manner, however, not met in the Church life, the illumination by the Holy Spirit of the Holy Fathers from different epochs etc. The Church has not understood, however, the work of God as a limited reality, but as a dynamic one, present in its living and spiritually healthy limbs. The meeting with the Holy Church Fathers, present in all its epochs, is transforming and empowering, so that patristic theology represents in the Church a unitary and indivisible fact.
\end{abstract}

Keywords: patristic theology; postpatristic theology; neopatristic synthesis; new patristic synthesis; Holy Father;

\section{INTRODUCTION}

One of the problematizations met in the contemporary Orthodox theology ${ }^{1}$ refers to the duration of the patristic period, in other words, the question is whether the division

* It should be noted that a first version of this study was presented at The International Symposium on Patrology, First Edition, organised by the Diocese of Severin and Strehaia in partenership with the Faculty of Orthodox Theology from Craiova, event which took place in the Monastery Saint Ana from Orşova, in 2014 (79 October).

${ }^{1}$ About certain problematizations, including also the topic of this study, see Ion Marian Croitoru, "The Growth of the Dogmatic Teaching in the Contemporary Orthodox World. Questions and Problematizations", International Journal of Orthodox Theology 6/1 (2015), p. 165-204; idem, "Problematizări privind creşterea învăţăturii dogmatice în lumea ortodoxă contemporană (Problematizations regarding the Growth of the Dogmatic Teaching in the Contemporary Orthodox World)", in Universitatea Ovidius, Facultatea de Teologie Sfântul Andrei, Tradiţie şi continuitate în teologia tomitană. Două decenii de învăţământ teologic universitar la Constanţa. 1992-2012. Simpozion Internaţional (2012, Constanţa) (Saint Andrew. Tradition and Continuity in the Theology of Tomis. Two Decennia of Academic Theological Education in Constanţa. 1992-2012. 
operated by the Western Christian doctrine regarding this period is acceptable or we are entitled to affirm that the period under discussion has continuity in the one, holy, catholic and apostolic Church to this day and will continue until the second coming of the world's Savior Jesus Christ.

1. According to the Western Christian doctrine, the patristic period is divided into three periods ${ }^{2}$ and ends in a certain century for the Christian world. Thus, for Western Christianity, it has been stated that the patristic period has as its last remarkable personalities: Saint Gregory the Great (†604) in Italy or Isidore of Seville $(\dagger 636)$ in Spain $^{3}$, the last centuries of the patristic literature being considered those of the years 430-850, followed afterwards by the age or the epochs of the great theologians and church doctors, who are, however, not part of the actual Patrology ${ }^{4}$. According to the same doctrine, the patristic period ended in the $8^{\text {th }}$ century, for Eastern Christianity ${ }^{5}$ and, beginning with that epoch, other theologies have been developed, which formulate the Church experience using the terms and the thinking of each epoch. For instance, for Western Christianity, it is considered that one of these theologies was, as the supporters of this division claim, the

International Symposium (2012, Constanţa)" (Constanţa: Editura Arhiepiscopiei Tomisului, 2012/2013), p. 204-23.

${ }^{2}$ It ought to be mentioned that the sequencing of these three periods depends from one patrologist to the next, and a general classification is as follows: the $1^{\text {st }}$ period, going from the activity of the Saviour Jesus Christ on earth and the Holy Apostles' preaching to 313 (The Edict of Milan) or 325 ( ${ }^{\text {st }}$ Ecumenical Synod); the $2^{\text {nd }}$ period, usually comprised between the $1^{\text {st }}$ Ecumenical Synod and the $4^{\text {th }}$ Ecumenical Synod (Chalcedon, 451), proposing as limits also the personality of Blessed Augustine $(\dagger 430)$ or that of Saint Cyril of Alexandria $(\dagger$ 444); and the $3^{\text {rd }}$ period, which has several limits, both for the West and for the East, without, however, going over the first half of the $9^{\text {th }}$ century. For instance, Cayre has the following proposition: the $1^{\text {st }}$ period, between the $1^{\text {st }}$ and the $3^{\text {rd }}$ century A.D.; the second period, between the years 300 and 430 ; the $3^{\text {rd }}$ period, during the interval 430-850 [F. Cayré, Précis de Patrologie et d'Histoire de la Théologie, Livres I et II (Paris, Tournai, Rome: Desclée et Cie, Editeurs Pontificaux, $\left.{ }^{2} 1931\right)$, p. 7; Ioan M. Bota, Patrologia (Patrology) (Cluj-Napoca: Editura Viaţa Creştină, $\left.{ }^{2} 2002\right)$, p. 17]. In the Roman-Catholic doctrine of the contemporary period, there is also the proposition that the ending date of the three patristical periods should be connected to three Ecumenical Synods: the $1^{\text {st }}$ Ecumenical Synod (Nicea, 325) for the $1^{\text {st }}$ period; the $4^{\text {th }}$ Ecumenical Synod (Chalcedon, 451), which concludes the $2^{\text {nd }}$ period; and the $7^{\text {th }}$ Ecumenical Synod (Nicea, 787) for the $3^{\text {rd }}$ period. After these three periods of the Holy Fathers follow the Theologians and spiritual Masters (Bota, Patrologia, p. 17-18, 397). More recently, it has been proposed to use the syntagm of early Christian Greek and Latin literature for the whole patristic period, taking as a last term of reference the $5^{\text {th }}$ Ecumenical Synod of Constantinople (553), with its last ramifications, mentioning, however, that for the Greek area there have never been any "limit dates", see Claudio Moreschini and Enrico Norelli, Istoria literaturii creştine vechi grecești şi latine, II/1, De la Conciliul de la Niceea la inceputurile Evului Mediu (The History of the Early Christian Greek and Latin Literature, II/I, From the Council of Nicea to the Beginnings of the Middle Ages), translation from Italian by Elena Caraboi, Doina Cernica, Emanuela Stoleriu and Dana Zămosteanu (Iaşi: Editura Polirom, 2013), p. 5; see also Damian Gheorghe Pătraşcu, Patrologie şi Patristică. Secolele I-IV (Patrology and Patristics. The $1^{\text {st }}$ $4^{\text {th }}$ centuries), vol. I (Roman: Editura Serafica, 2007), p. 15.

${ }^{3}$ See Ioan G. Coman, Patrologie (Patrology), I (Bucureşti: Editura Institutului Biblic şi de Misiune al Bisericii Ortodoxe Române, 1984), p. 31; Constantin Voicu, Patrologie (Patrology), I (Bucureşti: Editura Basilica a

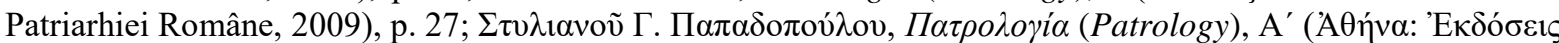

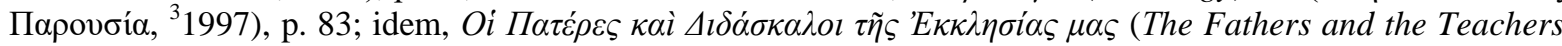

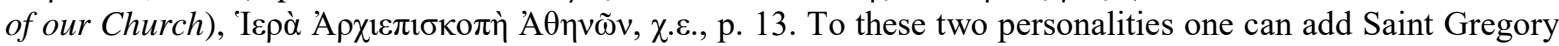
of Tours $(\dagger 594)$ in France and Saint Beda/Bede the Venerable $(\dagger 735)$ in England, see Cayré, Précis de Patrologie, p. 9.

${ }^{4}$ Cayré, Précis de Patrologie, p. 7-9; F. Cayré, Patrologie et Histoire de la Théologie, Livres III et IV (Paris, Tournai, Rome: Desclée et Cie, Editeurs Pontificaux, $\left.{ }^{2} 1933\right)$, p. 347.

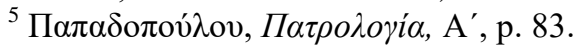


scholastic theology together with its representatives, who are considered the new theologians or Fathers of the Western tradition ${ }^{6}$. One of them was Thomas Aquinas (1224/1225-1274), who uses in his work, Summa Theologica, aspects of the teaching of Saint John of Damascus $(\dagger 749)$. In this way, according to the Christian tradition of the West, among the Holy Fathers of the first eight centuries is considered Saint John of Damascus, as well, with whom the patristic period of the East ends ${ }^{7}$.

2. This opinion has sneaked its way into the Orthodox world and has been appropriated especially by certain patrologists. As far as the Romanian side is concerned, the two official textbooks of Patrology, mostly for students' use, contain as accepted the perspective of the Western theology. According to the authors of the two textbooks (Fr. Ioan G. Coman, Archdeacon Constantin Voicu), the third and last period of Patrology starts from one of the final years of the second period [ $† 430$ (Blessed Augustine), 444 ( $†$ Saint Cyril of Alexandria), 451 (the $4^{\text {th }}$ Ecumenical Synod), 461 († Saint Leo the Great)] and ends in 749, namely in the year of Saint John of Damascus' dormition in Christ, or in 843, with the Sunday of the Orthodoxy, or even in 787, in other words, in the year of the $7^{\text {th }}$ Ecumenical Synod $^{8}$. Taking as a landmark this division, Father Ioan G. Coman even speaks about

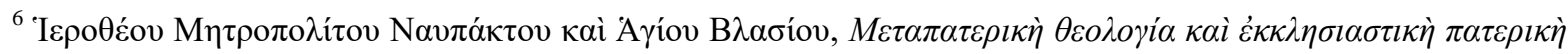

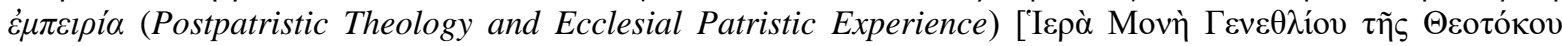

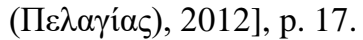

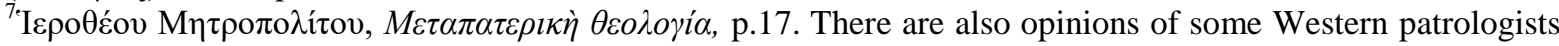
who, for the East, extend the last patristic period up to Saint Theodore the Studite $(\dagger 826)$ or even up to the beginning of the $9^{\text {th }}$ century, also including the end of the iconoclast debate (Cayré, Patrologie et Histoire, p.1-2).

${ }^{8}$ See Coman, Patrologie, I, p. 31; Voicu, Patrologie, I, p. 26-7. The position of the two Romanian patrologists was not unique, because long before them, Priest Cicerone Iordăchescu introduced in the theological literature and thinking of Romania, more precisely in the atmosphere of the Faculty of Theology of Chişinău (today, in Moldova), the classical division reminded above (see note 2), indicating as well its main source, the RomanCatholic patrologist Otto Bardenhewer, followed by the Protestant Adolf von Harnack, to whom he adds other names as well, Gerhard Rauschen, Albert Ehrhard and F. Cayré. Therefore, making first a synthesis of the above-mentioned patrologists' opinions, Father Iordăchescu presents the delimitation of the three periods: the $1^{\text {st }}$ period, comprising the first three centuries of the Church, until $325\left(1^{\text {st }}\right.$ Ecumenical Synod $)$; the $2^{\text {nd }}$ period, also called the Golden Age of the Christian literature, going from 325 to the year 430, in the West (the year of Blessed Augustine's death), and 444, in the East (the year of Saint Cyril of Alexandria's death), or even 461 (the year of Pope Leo the Great's death); the $3^{\text {rd }}$ period, starting from the middle of the $5^{\text {th }}$ century and going, in the West, up to Isidore of Seville's death ( $†$ 636), and in the East, up to Saint John of Damascus' demise ( $\dagger$ 749 ), proposing as landmarks as well the years 680 (the $6^{\text {th }}$ Ecumenical Synod), 787 (the $7^{\text {th }}$ Ecumenical Synod) or 843 (the triumph of the Orthodoxy), see idem, Istoria vechii literaturi creştine (Primele trei veacuri până la 325) [The History of the Early Christian Literature (The First Three Centuries up to 325)], vol. I (Chişinău: Tipografia Ţerek \& Caminschi, 1934; Iaşi: Editura Moldova, $\left.{ }^{2} 1996\right)$, p. VI-VII, p. 11-2; idem, Istoria vechii literaturi creştine (Epoca de la 461 la 636/750) [The History of the Early Christian Literature (The Epoch from 461 to 636/750)], vol. III (Chişinău: Tipografia Ţerek \& Caminschi, 1940; Iaşi: Editura Moldova, ${ }^{2}$ 1996), p. VII. Finally, Priest Cicerone Iordăchescu adopted Bardenhewer's division: the $1^{\text {st }}$ period up to 325 (the $1^{\text {st }}$ Ecumenical Synod); the $2^{\text {nd }}$ period, between the years 325-461 (Pope Leo the Great's death); the $3^{\text {rd }}$ period, during the years 461-636 ( $\dagger$ Isidore of Seville), for the West, and 461-749 ( $†$ Saint John of Damascus), for the East (Iordăchescu, Istoria vechii literaturi creştine, I, p. 12). For the classifications adopted in the two Textbooks quoted at the beginning of the note, one can notice that the $1^{\text {st }}$ period goes from the end of the $1^{\text {st }}$ century (92) to the beginning of the $4^{\text {th }}$ century, finally taking as a landmark the year 313 (The Edict of Milan); the $2^{\text {nd }}$ period ranges from 313 to different dates $(430,444,451,461)$, accepting as a last landmark the year 461, namely the date of Pope Leo the Great's death [Coman, Patrologie, I, p. 25, 27; Voicu, Patrologie, I, 25-26, see also Ioan G. Coman, Patrologie (Patrology) (Bucureşti: Editura Institutului Biblic şi de Misiune Ortodoxă, 1956), p. 11-2; for a presentation of the patristic epoch periodization according to the Roman- 


\section{patristic and postpatristic generations, and implicitly also about the patristic and} postpatristic tradition?'

However, in the latest Greek theological thinking, one can note the existence of two perspectives. According to the first perspective (Panagiótes Chrestos), the period of the Fathers continues at least until 1453, namely until the fall of Constantinople ${ }^{10}$. The second perspective (Stylianos Papadópulos ${ }^{11}$ ) rejects the existence of any limits in time for the patristic period, as this would signify a separation of the Fathers from the Church and, naturally, ignorance of what a Father and Teacher or what we commonly call Church Father means ${ }^{12}$. In the practice of the theological and Church language, the name of Holy

Catholic, Protestant and Orthodox patrologists, see M. Şesan, "Despre încheierea epocii patristice (On the Conclusion of the Patristic Epoch)", Mitropolia Moldovei și Sucevei 53/5-6 (1967): p. 362-4]. It should be mentioned that Father Constantin Voicu reedited his Textbook of Patrology [vol. I-II (Bucureşti: Editura Basilica a Patriarhiei Române, 2009), vol. III (Bucureşti: Editura Basilica a Patriarhiei Române, 2010)], in collaboration with Father Lucian-Dumitru Colda, in an extended and revised edition. The above-mentioned classical division of the patristic period is maintained, and in the $3^{\text {rd }}$ volume are also included postpatristic authors [Constantin Voicu, "Cuvânt înainte (Foreword)", in Constantin Voicu and Lucian-Dumitru Colda, Patrologie (Patrology), I (Bucureşti: Editura Basilica, 2015), p. 10; see also ibidem, p. 28-31]. The two authors, referring to patrologists who take the study of "Patrology" beyond the $8^{\text {th }}$ century, up to the $12^{\text {th }}$ and even the $15^{\text {th }}$ century, mentioning that this period is called postpatristic theology, affirm that it would be, therefore, necessary for the study of "Patrology" to go beyond the strict framework of the first eight centuries. However, they claim that we only have Holy Fathers during the first eight centuries of the Christian era; consequently, the study of "Patrology" covers only those eight centuries (ibidem, p. 21, 29). All the affirmations above confirm patrologist Adrian Marinescu's opinion, namely that since the $19^{\text {th }}$ century one can note this drawing close to and pursuit of the Western perspectives, first of all by "copying" the specialized textbooks, in their double manifestation: Roman-Catholic and Protestant, then by redundantly resuming some so-called main themes promoted by Western patrologists [idem, "Patrologia şi studiile de specialitate în cadrul Ortodoxiei din secolul al XX-lea şi începutul secolului al XXI-lea. Şcoli şi direcţii de cercetare (Patrology and Specialized Studies in the frame of the Orthodoxy in the $20^{\text {th }}$ Century and at the Beginning of the $21^{\text {st }}$ Century. Schools and research directions)", in Teologia ortodoxă în secolul al XX-lea şi la începutul secolului al XXI-lea (The Orthodox Theology in the $20^{\text {th }}$ Century and at the Beginning of the $21^{\text {st }}$ Century), coord. Fr. Viorel Ioniţă (Bucureşti: Editura Basilica a Patriarhiei Române, 2011), p. 307].

${ }^{9}$ See Ioan G. Coman, "Sfânta Tradiţie în lumina Sfinţilor Părinţi (The Holy Tradition in the light of the Holy Fathers)", Ortodoxia 8/2, (1956): p. 174, 186. The position of Father Ioan G. Coman is also appropriated by other younger Romanian patrologists, who divide the Christian literature into patristic and postpatristic, see Constantin I. Băjău, Patrologie (Patrology) (Craiova: Tipografia Universităţii, ${ }^{3} 2002$ ), p. 8, 438; idem, Patrologie şi literatură post-patristică (Patrology and Post-Patristic Literature) (Craiova: Editura Universitaria, 2013), p. 7, 337. There is also the opinion (Fr. M. Şesan) that even the postpatristic period, beginning with the years that follow the Sunday of the Ortodoxy (843), when the patristic epoch ends, and the age of Saint Photios the Great († 893), lasts until Michael Psellos († 1078), see Şesan, "Despre încheierea epocii patristice", p. 365-6.

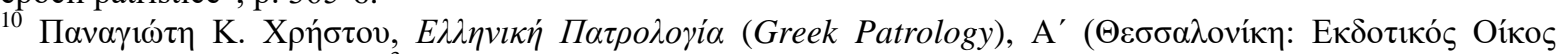

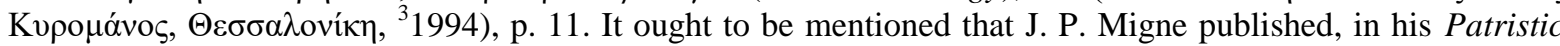
Collection, works covering a much longer period than the classical periods. Thus, in the Seria graeca (161 vol., Paris, 1857-1866), the printing of the works begins with Clemens Romanus and goes up to Constantine Palaiologos, namely from the year 90 up to the year 1453, when the fall of the Constantinople takes place, and in the Seria latina (221 vol., Paris, 1841-1864), the period is comprised between Tertullian and Innocent III, namely from the year 200 up to the year 1216 (Pătraşcu, Patrologie şi Patristică, p. 15, note 24).

${ }^{11}$ It is worth mentioning the spiritual standing of this Greek patrologist, who, two months before his departure to the Lord († 15 January 2012), becomes a monk and receives the name of Gerasimus. His tomb is at the Docheiariou Monastery of the Holy Mount Athos.

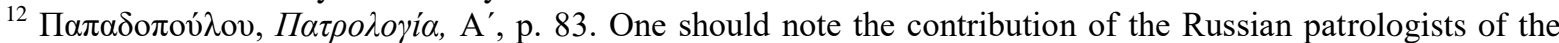
$19^{\text {th }}$ century, regarding the patristic period or epoch. For example, Archbishop Philaret (1805-1866) of Chernigov (1859-1866), considered the author of the first Orthodox textbook of Patrology [învăţătura istorică despre Sfinţii Părinţi (Historical Teaching on the Holy Fathers), 3 vol. (Petrograd, 1859), in Russian], although 
Father and Teacher is replaced by the simple form of Holy Father, which nevertheless shows that the respective person sums up, by his life and his activities, the attributes of shepherd of souls and teacher in Jesus Christ's Church. In other words, on the one hand, he takes care of the believers' spiritual guidance for them to get to unity with Christ by the Holy Spirit, he preaches to them the Gospel, he accomplishes for them the Holy Mysteries of the Church and is called for all these Father, and, on the other hand, he teaches the believers the Church teaching and interprets to them God's revelation, answering, at the same time, the great problems and theological crises from the Church. This thing does not mean that the other Saints are less Saints or less Orthodox than the Holy Fathers and Teachers; it simply means that they did not have the charisma specific of the Holy Father and Teacher. Actually, the Holy Fathers had and have different functions in the church [bishops, priests (Jerome, John of Damascus, Symeon the New Theologian etc.), deacons (Ephrem the Syrian etc.), monks (Macarius the Egyptian etc.), lay people (Justin the Martyr and Philosopher, Nicholas Cabasilas etc.)] and it is not meet to compare them with one another or divide them into categories, because all of them have been organs of God, have fulfilled their calling and have successfully served the Church, namely man's salvation ${ }^{13}$.

3. The characteristic features of a Holy Father and Teacher of the Church are: a) the embodiment, from a theological perspective, of the Church Tradition and way of living; b) the illumination par excellence by the Holy Spirit to express theologically a grown and larger experience of the eternal Truth Himself, Who is declared in the Tradition, namely in the patristic theology confirmed previously, but also in the Holy Scripture; c) the decisive contribution, by expressing this divine experience, to overcoming a theological crisis, which has shaken the Church during a certain epoch, regarding both the authentic living of the Truth and, at the same time, man's salvation ${ }^{14}$. By the three qualities or features enumerated above, the Greek patrologist Stylianos Papadópulos affirms, on the one hand, that a clearer distinction is made between the Holy Fathers and Teachers of the Church and the Church writers $^{15}$. On the other hand, he considers that the classical features met in the Patrology

dividing the patristic period into four periods (70-312, 312-620, 620-850, 850-1206), affirms in the Preface of the respective textbook that there are no limits to the patristic period, and the opinions setting as a limit of the patristic period the $6^{\text {th }}$ or the $13^{\text {th }}$ century are not grounded. This position gets to be known both to the Greek

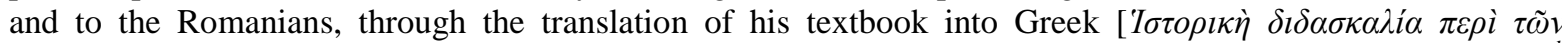

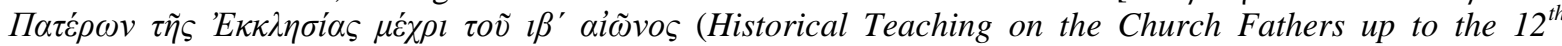

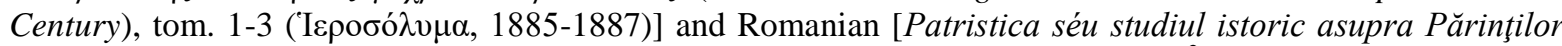
Bisericei (Patristics or Historical Study on the Church Fathers) (Bucureşti: 1879, ${ }^{2} 1880$ )]. At the same time, Archbishop Philaret (1782-1867) of Moscow (1821-1867), one of the most important supporters of the project of translations of the Holy Fathers into Russian, formulated the demand that in the Academies of Moscow, Petersburg and Kiev, and then in the one of Kazan, as well, the study of the Holy Church Fathers should extend in time up to the end of the $18^{\text {th }}$ century, being included also the work of Saint Tikhon of Zadonsk, proclaimed a Saint only in the year 1861. The positions of the two archbishops and patrologists show the conviction that the patristic period was contemporary to them [Marinescu, "Patrologia şi studiile de specialitate", p. 308-13; see also Sophie Deicha, "Impulsion donnée par le Métropolite Philarète de Moscou (1782-1826) aux études patristiques en Russie au XIX ${ }^{\mathrm{e}}$ siècle", Studia Patristica XXIII (1993), p. 226-31].

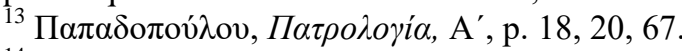

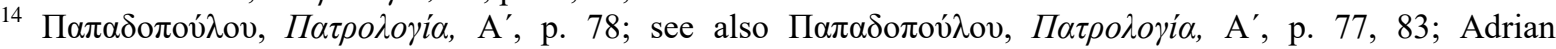
Marinescu, "Criteriile şi fundamentele patristice ale teologiei, elemente structurale ale teologiei ortodoxe dintotdeauna şi premize ale rezolvării problematicii teologice de astăzi (The patristic criteria and fundaments of theology, structural elements of the Orthodox theology since always and premises for solving today's theological problems) (I)", Studii Teologice 9/2 (2013): p. 264.

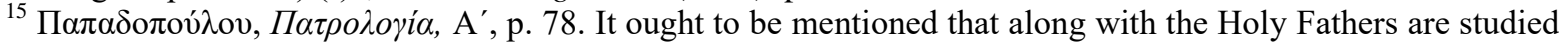
also the other Church writers, whose name is great and whose works are innumerable. Actually, the Holy 


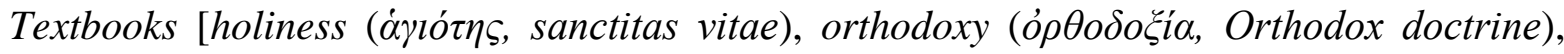

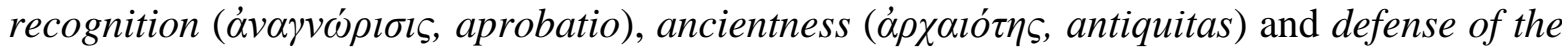

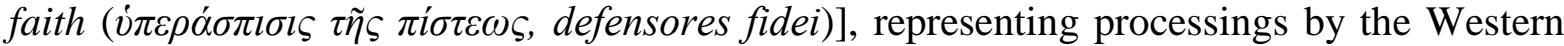
theologians, are scholastic and conventional, triggering problems, according to the same patrologist. If one were to refer to some of these features, one could ask, for instance, based on what criterion ought the holiness of Saint Cyril of Alexandria to be researched, who, although he has certain mistakes ${ }^{16}$, is nevertheless considered a Holy Father and Teacher of the Church. Ancientness represents, therefore, a utopic feature, since the Holy Father's expression of truth is appropriated or rejected during the epoch when it has been made known, and the Church does not wait for centuries to honor the author whose teaching she has appropriated. Actually, in the bosom of the Church, there are Fathers and Teachers not just during the early Christian epoch but also during the subsequent as well". "The Golden Age", inaugurated by Christ, by the Apostles and by the early Fathers, is continued in the works of the Church Fathers of our times ${ }^{18}$. As far as the defense of the faith is concerned, this is realized not just by Holy Fathers and Teachers, but also by Church writers ${ }^{19}$ and lay believers of the Church.

In this way it becomes clear why the Church, in her conscience, does not despise the one who has been wrong, because she knows very well that a Father will not become less of a Father because he has made a certain mistake. Important is that the respective Holy Father should not continue in this mistake. The classical example is the position of the Holy Cappadocian Fathers towards Saint Athanasius. The first ones did not follow the second in what he said about the identity between being and hypostasis, but honored him for his subsequent contribution as their greatest teacher ${ }^{20}$. Therefore, the patristic theological contribution is moving in between two ascertainments: a) the Holy Fathers theologize by the illumination of the Holy Spirit and the intellectual gifts specific of each one of them; b) the Holy Fathers make mistakes in certain cases. The fact of illumination is highlighted by the reality that their teachings are appropriated by the Church, because they agree with the Holy Scripture and with the decisions of the Ecumenical Synods, and, consequently, also with the Holy Tradition, in which they are incorporated as well. The fact of the mistake of certain Holy Fathers is noticed by the attitude of the Church, who does not appropriate the respective wrong teachings, these being rejected and forgotten. For instance, the millenarist conceptions of Irenaeus, or all that Athanasius the Great affirmed on the identity between being and hypostasis in God or even the conception of Gregory of Nyssa on the apokatastasis of all and many other cases of greater or lesser importance ${ }^{21}$. This conscience of the Church is explained by Saint Photios the Great, underlining the fact that if some Holy Fathers spoke reticently about certain things or deviated from the right path out of some

Fathers' theological contribution represents the core around which all the other Christian literature generally revolves. The latter can, up to a certain point, be characterized as interpretation or comment on the Fathers' vital contribution, as long as this contribution creates, by addition and growth, the whole Tradition

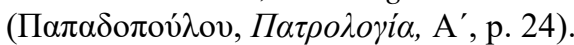

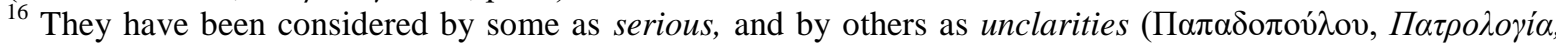

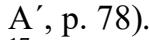

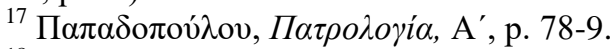

18 Episcopul Hilarion Alfeyev, "Moştenirea patristică şi modernitatea (Patristic Heritage and Modernity)", translation by Ştefan Toma, Revista teologică 17 (89)/2 (2007): p. 26.

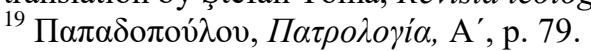

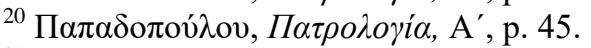

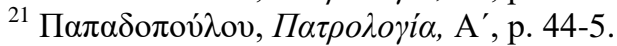


unknown reason, but, nevertheless, no objection has been brought against them, nor have they been exhorted by someone in particular to teach the truth, then they are nonetheless considered Fathers and Teachers, with the difference that the words in which they were wrong are not followed ${ }^{22}$. Therefore, the common experience of the Saints and the illumination are guarantees of an accurate expression of the truth, which always moves within a therapeutical approach and not within an axiological classification ${ }^{23}$.

From the history of the Church, one can note, however, that the three elements mentioned above, characterizing a theologian as Church Father and Teacher, and also making his work be expressed under different forms (catechesis, sermon, hermeneutics, apologetics, polemic theology, poetry, narrative of divine experiences and of states of vision of God, description of the stages of the neptic life, narrative of the Saints' lives, composition of Synodal texts and decisions etc. $\left.{ }^{24}\right)$, exist regardless of the epochs ${ }^{25}$. In other words, any theological crisis expressed under the form of a heresy and endangering the authentic living of the Truth and, consequently, the believers' salvation, may occur at any place and at any time. To be able to meet such a crisis, it is certainly necessary to have a more intense experience of the Truth $^{26}$, which experience, expressing the truth of the Holy Scripture ${ }^{27}$ and the continuity of the Holy Tradition, guarantees the faith, the kind of faith able to assure people's salvation. One can note that, during each epoch, when the content of faith is altered and the believers' salvation becomes doubtful, the Holy Spirit brings to light in the Church great theologians, through whom any wrong teaching is refuted. Therefore, as long as the Church is history ${ }^{28}$, it will have Fathers. Consequently, "Patrology", also considered a branch of the theological science, has no limits in history, just as the Church Tradition has no limits $^{29}$, nor can it be multiform, but is only one, as Christ's Church is one ${ }^{30}$, and this

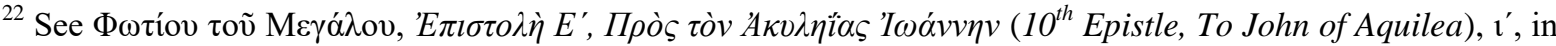

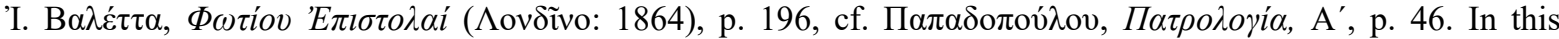
context, the concept of consensus patrum (accord or consent of the Fathers), borrowed from Western theology, supposes, from the perspective of the Orthodox theology, the Holy Fathers' consent in essential matters, with the possibility of some divergences in minor problems. When in a Holy Father's works one can note some opinion contradicting other Holy Fathers' teachings, we should not hesitate to reject it as a "personal theological opinion", falling out of the "Father's consent" (Episcopul Hilarion, "Moştenirea patristică”, p. 27).

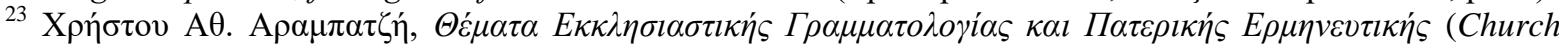

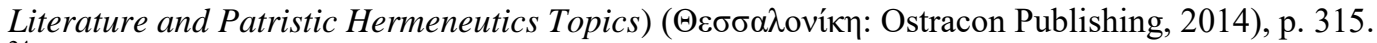

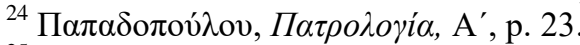

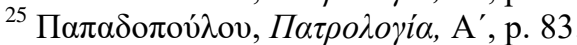

${ }^{26}$ It should be mentioned that truth, according to the theological terminology, designates both the divine reality itself, and the fact of experiencing or knowing it, see П $\alpha \pi \alpha \delta \mathrm{o} \pi \mathrm{ov} \lambda \mathrm{ov}, \Pi \alpha \tau \rho o \lambda o \gamma i \alpha, \mathrm{A}^{\prime}$, p. 36.

${ }^{27}$ The Holy Fathers saw and see the Holy Scripture as being an expression and formulation of the Truth and not the Truth Himself, Who, naturally, can be comprised in no book and no form at all. They were [and are] aware that the text of the Scripture, as expression and form, represents a sort of symbols, used conventionally and with the consent of those interested, to express fundamental redeeming aspects of the divine truth

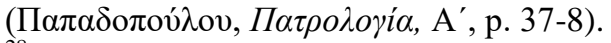

${ }^{28}$ It has been adequately affirmed that history, from the Christian perspective, is a permanent Theophany, while God's birth of a woman, namely of the All-holy Virgin Mary, as God-man represents the revelation (2

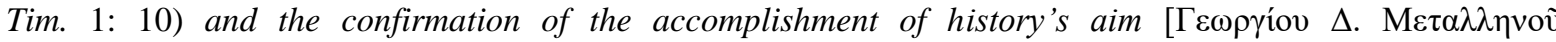

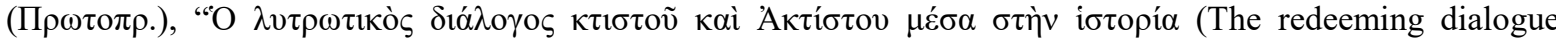

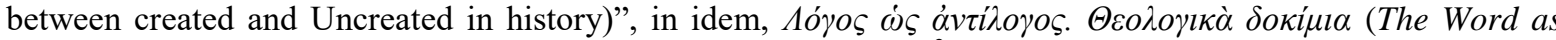

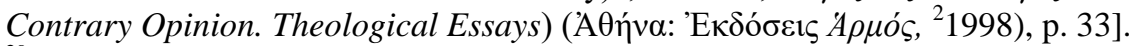

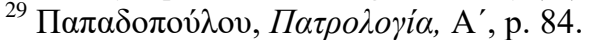

${ }^{30}$ Saint Ciprian, Letter 74, 4 (ed. Hartel), vol. III, 2, p. 802.
} 
Holy Tradition is the work of the Holy Spirit ${ }^{31}$, Who is at work in the one Church of Christ. And the Tradition cannot have limits precisely because the Fathers are not just its authentic bearers, but also its creators, in other words, dynamic continuers ${ }^{32}$ of the spiritual and dogmatic heritage of the Church, for they theologize under the Holy Spirit's guidance and illumination $^{33}$, a fact that indicates precisely the dynamic character of the Holy Tradition ${ }^{34}$.

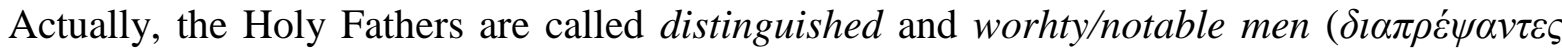

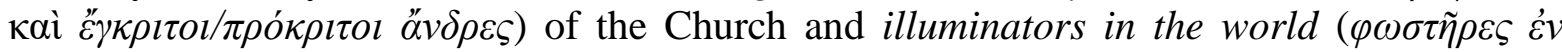

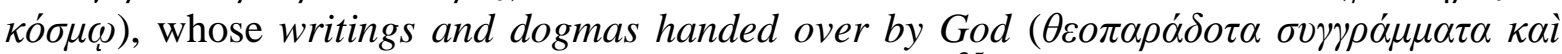
$\delta o ́ \gamma \mu \alpha \tau \alpha)$ have been kept and appropriated by the Church $^{35}$, since each teaching revealed is a work of God for man's salvation, which has been realized authentically in all the epochs, from the first century to this day ${ }^{36}$.

Consequently, there is no end to the Holy Fathers' epoch ${ }^{37}$ and we can set no limit to the Holy Fathers' emergence and action, who have been revealed by the Holy Spirit during different periods of the Church history (for instance, Saint Symeon the New Theologian during the $11^{\text {th }}$ century, Saint Gregory Palamas during the $14^{\text {th }}$ century etc. $)^{38}$, for the very reason that their group is not closed, and, by their presence, "Patrology" has a permanent theological character, since theology in the Church can only be "patristic", and not at all "postpatristic" or "neopatristic" "39. If "Patrology" loses its theological character, then it loses its identity, its orientation, namely it is laycized, it becomes a lay science completely powerless when it comes to interpreting theologically the Holy Fathers' achievements ${ }^{40}$. Such a secularized approach could not justify the efforts of the Church meant to ensure the unity of faith and the integrity of the theological ethos, understanding by this ethos the patristic way of thinking and living, which is recorded, for instance, in the History of Dogmas and of Spirituality, since dogma, in its turn, is the fruit of the holy-spiritual living and experience ${ }^{41}$, opening an infinite horizon of life and freedom, being the expression of the divine love ${ }^{42}$. For this reason, approaching the History of Dogmas, from the perspective of

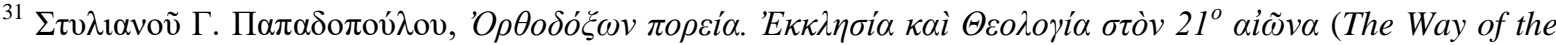
Orthodox. The $21^{\text {st }}$ Century Church and Theology) ('A $\theta \eta \dot{v \alpha: ~ ' E \kappa \delta o ́ \sigma \varepsilon เ \varsigma ~ Г \rho \eta \gamma o ́ \rho \eta, ~ 2012), ~ p . ~} 70$.

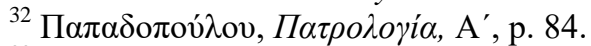

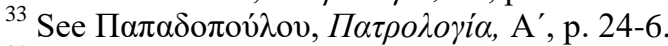

${ }^{34}$ From this perspective, a difference is made between the Holy Tradition and the local customs and traditions of a people, because the latter, however positive they may seem for the life of the Church, do not aim her

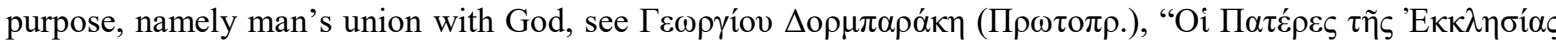

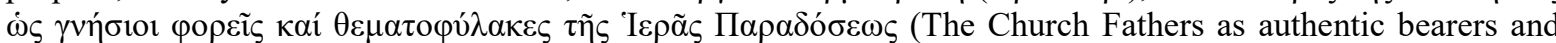

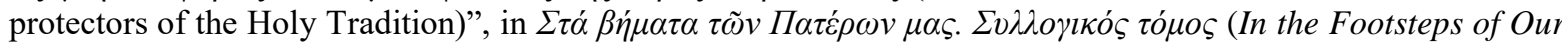

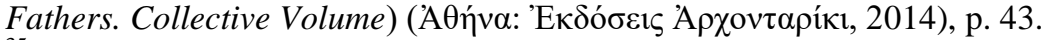

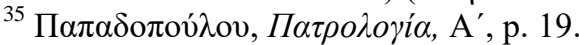

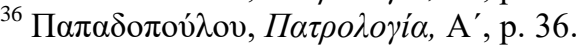

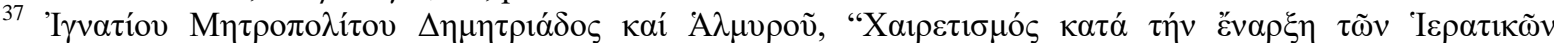

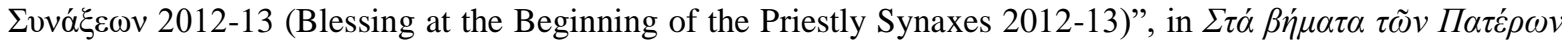
$\mu \alpha \varsigma \ldots$, p. 20.

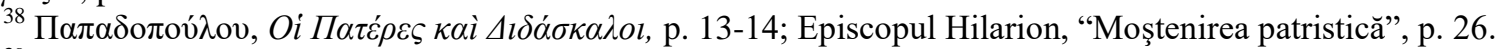

39 Gheorghe Holbea, "Raportul dintre teologia patristică şi teologia post-patristică (The relation between patristic and post-patristic theology)", Ortodoxia 4/2 (2012): p. 116.

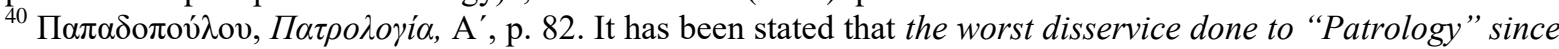
the middle of the last century is that it has been cultivated particularly as a historical-philological science

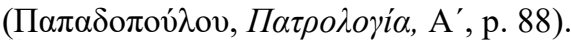

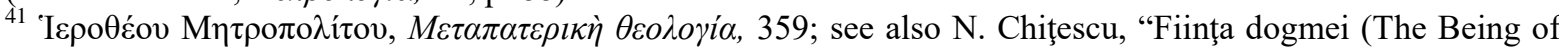
the Dogma)", Studii Teologice 5/3-4 (1953): p. 188-209.

${ }^{42}$ Holbea, "Raportul", p. 119.
} 
the Orthodox teaching, is not limited to the classical periods into which the Western Christian doctrine has divided the patrological material, but follows the entire dimension of the Church history ${ }^{43}$.

4. Accepting a terminus for the patristic period would trigger many consequences, such as: a) doubting the presence of the Holy Spirit in the Church; b) ranking, in a manner never met, however, in the Church life, the illumination of the Holy Fathers by the Holy Spirit during different epochs; c) betraying the spirit of the Holy Church Fathers by not understanding accurately their manner of living and thinking; d) underestimating the crisis phenomenon and its approach by the Holy Fathers and Teachers of the Church; e) using philosophic criteria regarding the Holy Fathers' theology and teaching; f) turning to the Holy Fathers" authority only out of an act of "erudition" 44 and attributing to them, willingly or unwillingly, interpretations that are totally foreign to their teaching ${ }^{45}$. For this reason, the Holy Fathers ought not to be reduced to simple "spiritual instances" or "theological options" that one can use only to defend one's own theological affirmations, being therefore

\footnotetext{
${ }^{43}$ For instance, the distinguished professor Constantine Scutéris projected his monumental work on The History of Dogmas, of which only two volumes have appeared (Athens, 1998 and 2004), into four periods: 1) from Jesus Christ's preaching until the years that preceded the $1^{\text {st }}$ Ecumenical Synod (Nicea, 325); 2) from the $1^{\text {st }}$ Ecumenical Synod to the $7^{\text {th }}$ Ecumenical Synod (Nicea, 787); 3) from the $7^{\text {th }}$ Ecumenical Synod until the years of the Reformation in the West, along the $16^{\text {th }}$ century; 4) from the Reformation to our days. Yet, the author makes the mention that he has made use of this periodization out of reasons that clearly concern the research and presentation method, and the inner connection and the matching of the material of The History of Dogmas,

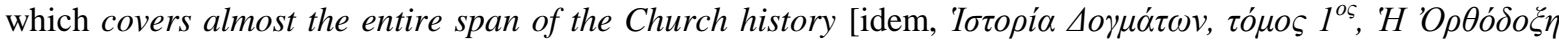

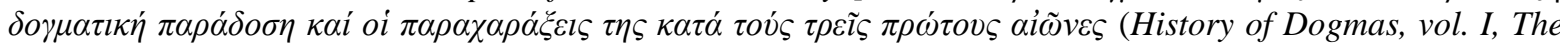

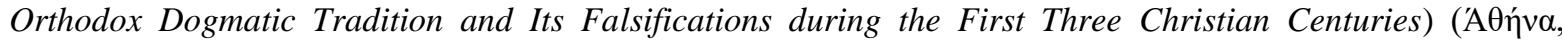
1998), p. 16-8]. Jaroslav Pelikan had the same vision in the monumental work The Christian Tradition. A History of the Development of Doctrine (vol. I-V, 1971, 1977, 1978, 1983, 1987), finished before his passage from Lutheranism to the Orthodoxy (1997). In the Preface to the first volume, he confesses that he proposes a unitary vision on the Christian Tradition and takes on the daring, yet, at the same time, necessary task of starting from the origins of the Christian doctrine history to go up to the $20^{\text {th }}$ century, while maintaining the distinctions between the Christian Churches \{idem, Tradiţia creştină. O istorie a dezvoltării doctrinei. I. Naşterea traditiei universale (100-600) [The Christian Tradition. A History of the Development of the Doctrine. I. The Birth of the Universal Tradition (100-600)], translation from English by Silvia Palade (Iaşi: Editura Polirom, 2004), p. 11\}.

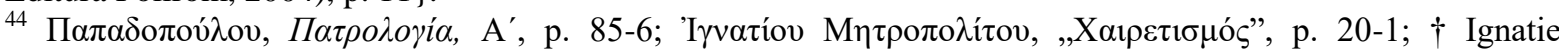
Mureșeanul, "Elemente de isagogie în studiul patristic (Elements of Isagogics in the Study of Patristics)", p. 12, http://comptepv.typepad.fr/files/elemente-de-isagogie-patristica.pdf (accessed on July 25, 2015); Juan José Ayan Calvo, "Mâna creatoare a lui Dumnezeu (God's Creating Hand)", in Cristian Bădiliță, Ştiinţă. Dragoste. Credinţă. Convorbiri cu patrologi europeni (Science. Love. Faith. Dialogues with European Patrologists), Col. "Ştiinţă şi Religie (Science and Religion)" (Bucureşti: Editura Curtea Veche, 2008), p. 95; Adrian Marinescu, "Ortodoxie şi ortopraxie. Reflecţii privind importanţa, autoritatea şi actualitatea Părinţilor pentru omul contemporan (I) [Orthodoxy and Orthopraxy. Reflections on the Fathers' importance, authority and topicality for the contemporary man (I)]", Tabor 5/12 (2012): p. 32.

${ }^{45}$ See, for instance, the concepts of "person" and "individual" with Saint Gregory of Nyssa, together with the other Holy Cappadocian Fathers, and the erroneous interpretation of these concepts with John Zizioulas, metropolitan of Pergamon, in his attempt of making them forerunners of the modern personalism or of rejecting certain modern components of the concept of "person", in Lucian Turcescu, «"Person" versus "Individual”, and Other Modern Misreadings of Gregory of Nyssa», in Cristian Bădiliță, Charles Kannengiesser (éd.), Les Pères de l'Eglise dans le monde d'aujourd'hui. Actes du colloque international organisé par le New Europe College en collaboration avec la Ludwig Boltzmann Gesellschaft (Bucarest, 7-8 octobre 2004) (Paris: Beauchesne, Bucureşti: Curtea Veche, 2006), p. 311-26; see also idem, Gregory of Nyssa and the Concept of Divine Persons (New York: Oxford University Press, 2005).
} 
"instrumentalized" or reduced to the status of "archeological relics" $"$, nor is it meet to separate them into hermeneuts of the Holy Scripture, historians, dogmatists, polemists etc., because their aim is not hermeneutics, dogmatics or history. On the contrary, they have taken and they have as their basis the Holy Scripture and they have processed and put together the theological contribution of the Holy Fathers that preceded them, to provide an answer to certain theological challenges of their epoch in order to strengthen the believers spiritually ${ }^{47}$. At the same time, the Holy Fathers are authentic bearers of the Holy Tradition, having the experience of the Holy Spirit's work into them ${ }^{48}$. This experience, on the one hand, shows the Holy Spirit's work in the Church, by which the way of living in Christ is transmitted, from generation to generation, and, on the other hand, indicates the dynamism of the Holy Tradition $^{49}$.

The world's Savior, the Lord Jesus Christ and God's Son, said that He would give His disciples, namely the ones who live the faith in Him, the Holy Spirit, leading any man who purifies himself and gets to be illumined to the knowledge of the Truth. Therefore, He did not say that He would give Ecumenical Synods, but the Holy Spirit leading to all the truth $^{50}$, which means that it is not the synod that makes the Holy Fathers; on the contrary, it is the Holy Fathers who, being illumined and inspired by God, give authority to a synod and make it represent the authentic expression of the Truth ${ }^{51}$. Consequently, the authentic expression of the Truth relies on the experiencing of the Truth, which means a greater perception and knowledge of the Truth, by the work of the Holy Spirit, because the Truth Jesus Christ is not known exhaustively, being unlimited ${ }^{52}$. Therefore, the Ecumenical Synods' theology and decisions cannot be understood without the Holy Fathers and Teachers' theological contribution, which precedes and prepares, more or less, the ground for the acceptance of the correct standpoint by the whole Church. Yet, the acceptance of a patristic theological standpoint does not depend on the agreement or not of the majority of the Church body, as it has been so intensely claimed, but there are two premises regarding the orthodoxy and the acceptance of a patristic theological standpoint: a) the traditionality of the standpoint, namely its agreement with the Holy Scripture, the Holy Tradition and the entire way of living of the Church; b) the proceeding of this standpoint from the illumination of the Holy Spirit, poured in the Church through persons, not through institutionalized forms ${ }^{53}$.

5. A correct perception and [an accurate] interpretation of the Holy Father require for the penetration in the spiritual climate of the Holy Father, meaning participation to the experiences expressed by the Holy Father. The starting point in the effort to understand the Holy Father is, at the same time, his person and his work. Seeking the person facilitates the explanation of the work. By the work we approach the person, and, by the person, the work $^{54}$. Therefore, what is important is to follow the person creating, time after time,

\footnotetext{
46 † Ignatie Mureşeanul, "Elemente”, p. 2; Calvo, "Mâna creatoare”, p. 95; Episcopul Hilarion, "Moştenirea patristică", p. 25-6.

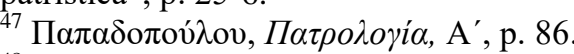

${ }^{48} \Pi \alpha \pi \alpha \delta$ олои́

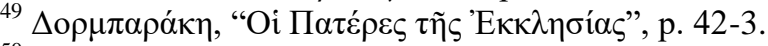

${ }^{50}$ John 16, 13.

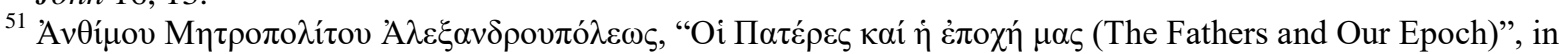

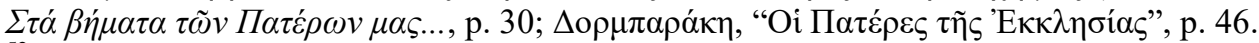

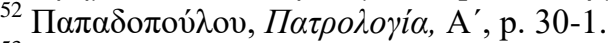

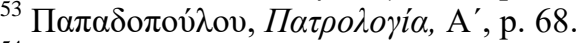

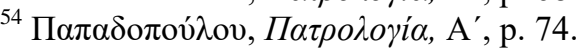


theology. Only the person stands out in the unitary area of theology and only the person represents the smaller or bigger stage on the way of theology ${ }^{55}$, and the indication about the way the dogmatic teaching grows, since these two, namely theology and the dogmatic teaching, represent an organic unity in the Church $^{56}$, just as the Holy Scripture and the Holy Tradition represent the unitary way of theology, the expression of the divine truth, which saves man in the Church ${ }^{57}$. The Holy Fathers' contribution consists, beside the example of a life led in the Church by their full living of Christ's teaching, in the growth in the knowledge of the Truth, Who is Jesus Christ Himself, God's Son and the world's Saviour. The divine revelation has been accomplished in and by Jesus Christ, not in a static, but in a dynamic manner, because it continues, not in the sense of discovering a different Truth, since only Jesus Christ is the way, the truth and the life (John 14: 6), but by experiencing the Truth ${ }^{58}$, which represents a permanent state in the Church and leads to the growth of the content of the Holy Tradition, but also of the Church ${ }^{59}$. Consequently, the Holy Fathers are not people who once belonged to the Church, but they continue to exist on earth and to belong to the Church to this day. Actually, the Church is not old but contemporary, permanently renewed $^{60}$, and lived and lives with [Holy] Fathers and Teachers ${ }^{61}$, who have been enriching and widening the Holy Tradition by the work of the Holy Spirit.

The Church, just as in the past, also in the future, will have its "great» men, namely its Holy Fathers and Teachers ${ }^{62}$. Saint Gregory the Theologian, referring to Saint Athanasius the Great - who, observing the problems created by Arius, joined at the right time ${ }^{63}$ the disputes of his epoch, healing the disease in the Church $^{64}$ - affirms that many and great are, therefore, the Holy Church Fathers and Teachers, so much so that no one could tell how many and how great they are, whom we have and and will have from God ${ }^{65}$.

6. It ought to be mentioned that, in the Romanian area, one can also note the standpoint of the passage from the neoscholastic to the neopatristic model, yet as a creative return to the patristic theology, according to Father Gheorghe Florovsky's perspective, announced in two essays that he himself presented during the first International Congress of the Faculties of Orthodox Theology, held in Athens, in $1936^{66}$. It should be specified that,

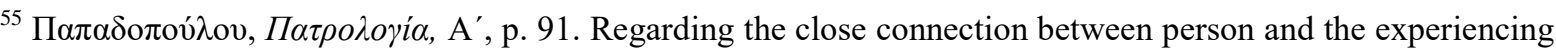
of the divine truth see also Marinescu, "Ortodoxie şi ortopraxie, I", p. 42; Adrian Marinescu, "Ortodoxie şi ortopraxie. Reflecţii privind importanţa, autoritatea şi actualitatea Părinţilor pentru omul contemporan (II) $-\mathrm{Cu}$ un studiu de caz privind fenomenologia patristică şi (re)contextualizarea ei în societatea contemporană [Orthodoxy and Orthopraxy. Reflections on the Fathers' importance, authority and topicality for the contemporary man (II) - With a case study on the patristic phenomenology and its (re)contextualization in the contemporary society]", Tabor 6/7 (2012): p. 29 - note 49, 45.

${ }^{56}$ Marinescu, "Ortodoxie şi ortopraxie, II", p. 11.

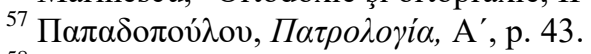

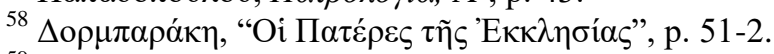

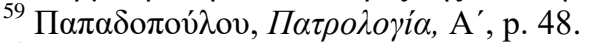

${ }^{60}$ Marinescu, "Ortodoxie şi ortopraxie, I", p. 33, 50.

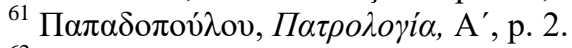

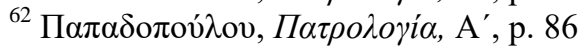

${ }^{63}$ Saint Gregory the Theologian, The $31^{\text {st }}$ Discourse 7, PG 35, 1098 A.

${ }^{64}$ Saint Gregory the Theologian, The $31^{\text {st }}$ Discourse 14, PG 35, 1096 C.

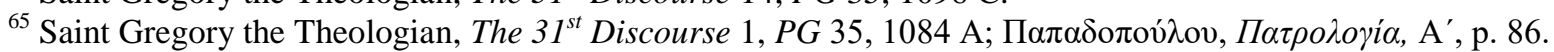

${ }^{66}$ For the perspective he stands up for, see G. Florovsky, "Westliche Einflüsse in der russischen Theologie", in Procès-verbaux du Premier Congrès de Théologie Orthodoxe à Athènes, 29 novembre-6 décembre 1936, publiés par les soins du Président Prof. Hamilcas S. Alivisatos (Athènes: Editions Pyrsos, 1939), p. 212-31; idem, "Patristics and Modern Theology", in Procès-verbaux du Premier Congrès, p. 238-42.
} 
during the same period, in France (1937), a project of translations, studies and comments of the Fathers, particularly of the Greek Fathers, was started. This fact marked, on the one hand, certain Roman-Catholic theologians and erudites' desire of unification between their Church and the Orthodox Church, and, on the other hand, an escape from the Latin juridism and rationalism, through the return to the Greek Fathers. This project, whose founders are the Jesuits Jean Daniélou (1905-1974), Pierre Chaillet (1900-1972), Henri de Lubac (18961991) and Claude Mondésert (1906-1990), will lie at the basis of the collection Sources Chrétiennes, launched in $1941^{67}$, and, later on, of the organization of the First International Conference on Patristics Studies at Oxford, in $1951^{68}$, which has continued the series of its reunions to the present epoch. Father Claude Mondésert, sent by Jean Daniélou to the $7^{\text {th }}$ International Congress of Byzantine Studies (Brussels, 1948), to present the collection Sources Chrétiennes, upheld the unity of culture from the Apostolical Fathers - and even from Philo - to Saint Bernard († 1153), in the West, and Saint Nicholas Cabasilas († 1391), in the East, Saint Gregory Palamas († 1359) being included as well, which means the extension of the patristic period up to the above-mentioned authors ${ }^{69}$. One can observe that the well-known collection Sources Chrétiennes appeared precisely at the moment when the Roman-Catholic Church had adopted officially the scholastic theology, which it considered as a progress and an indispensable and definitive clarification of the faith, whereas the reference to the Fathers seemed a turning back in time. Yet, the Second Vatican Council acknowledged the Fathers' irreplaceable role as first interpreters of the Christian mystery ${ }^{70}$.

As far as the Christian Orthodox world is concerned, Father George Florovsky's call was quickly received by the Orthodox theologians of the Russian Diaspora in the West (Vladimir Lossky, Archimandrite Ciprian Kern, Archbishop Basil Krivocheine, Myra LotBorodine, Father John Meyendorff), finding, however, supporters as well in the countries of Orthodox tradition, such as in Greece (Father John Romanidis), Serbia (Saint Iustin Popovici) and Romania (Father Dumitru Stăniloae). The last three mentioned above identified themselves with what is called patristic practice and tradition ${ }^{71}$, highlighting in

\footnotetext{
${ }^{67}$ Appreciated as well in the Orthodox Christian world, this collection had, in 2006, when it celebrated 66 years of activity, 500 volumes, of which 10 belong to the Hebrew literature, 238 to the Greek literature (49\% or half of them), 164 to the Roman-Catholic or Latin literature (33.8\% or a quarter of them), 70 to the medieval literature of the West $(14.4 \%)$ and 13 to the Eastern literature $(2.6 \%)$. As time, 115 volumes cover the period of the $1^{\text {st }}-3^{\text {rd }}$ centuries $(23.5 \%), 288$ volumes belong to the $4^{\text {th }}$ to the $8^{\text {th }}$ century $(59.3 \%)$ and 82 volumes are from the period of the $8^{\text {th }}$ to the $16^{\text {th }}$ century $(16.9 \%)$ [Dominique Gonnet, s.j., "La portée œcuménique de Sources Chrétiennes", in Patristique et ocuménisme. Thèmes, contextes, personnages. Colloque international sous le patronage de Mgr Teodosie, Archevêque de Tomis Constanţa (Roumanie), 17-20 octobre 2008, éd. Cristian Bădiliţă, Collection PONTUS EUXINUS (Paris: Editions Bauchesne, Târgu Lăpuş: Editura Galaxia Gutenberg, 2010), p. 28-30].

${ }^{68}$ The initiative belonged to a mixed team, made up of two Roman-Catholics, the Jesuit Jean Daniélou and the Dominican François Sagnard (1898-1957), and two Anglicans, the pastors Frank Leslie Cross (1900-1968) and Patrick McLaughlin (1909-1988). In the context of the epoch, the participation of Jean Daniélou was excluded by Jean-Baptiste Janssens (1889-1964), superior of the Jesuit Order, at the pressure of the Holy See, which was reserved to the initiative coming also from the Anglicans, which looked like an ecumenical reunion, having an active Roman-Catholic participation [Gonnet, s.j., "Sources Chrétiennes", p. 25; for details see Etienne Fouilloux, Les Catholiques et l'unité chrétienne: du XIX ${ }^{e}$ au XX $X^{e}$ siècle, itinéraires européens d'expression française (Paris : Le Centurion, 1982), p. 885].

${ }^{69}$ Gonnet, s.j., "Sources Chrétiennes", p. 24; see also Etienne Fouilloux, La collection « Sources chrétiennes » : éditer les Pères de l'Eglise au XX $X^{e}$ siècle (Paris : Cerf, 1995), p. 148-9; Claude Mondésert, "La collection « Sources Chrétiennes »", Byzantion XX (1950): p. 382-5.

${ }^{70}$ Gonnet, s.j., "Sources Chrétiennes", p. 29.

${ }^{71}$ Marinescu, "Criteriile (I)", p. 296.
} 
their works the role of the restoration of the patristic spirit, namely the way of spiritual thinking and living specific of the Holy Fathers ${ }^{72}$.

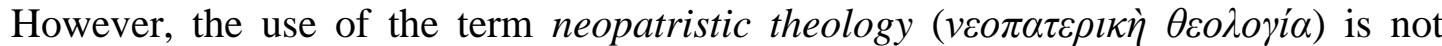
adequate, precisely because it leaves room for understanding that a period of patristic theology is over and now we are in a new period, no matter how much this last period were to be considered as a continuation of the first ${ }^{73}$. Concerning the patristic renewal of the $20^{\text {th }}$ century, called neopatristic synthesis (

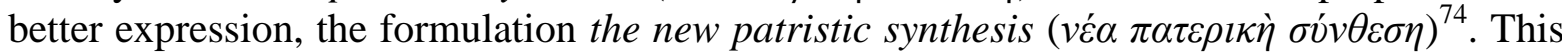
formulation does not betray the interpretation that Father Florovsky himself gives to the expression neopatristic synthesis, which he conceives as patristic, in other words, faithful to the spirit and the vision of the Holy Fathers, ad mentem Patrum, but also neopatristic, in the sense that, on the one hand, it adresses a new generation, with its own problems and questions ${ }^{75}$, while, on the other hand, it leads to a development and a continuation of the patristic teaching, yet, homogenous ${ }^{76}$, since the same Father states that it is impossible to limit the patristic period to a period or the other ${ }^{77}$. Therefore, the patristic theology, based on the patristic experience, namely on the living of the states of purification, illumination and deification, holds solutions to all the problems of the past, of the present and of the future ${ }^{78}$, because these solutions are given by the Holy Church Fathers, contemporary to a man either by the topicality of their teachings and the power of the prayers to them, if they have lived during past periods of time, or by their presence in the present time. For this reason, Father Florovsky sees the return to the Holy Fathers not just as a means of preserving the patristic experience, but also as a means of rediscovering it, so that this experience may pass into the life of the man of any epoch ${ }^{79}$.

72 Ioan Moga, "Despre maladiile teologiei. Marginalii la o temă actuală (On the maladies of theology. Marginalia to a topical theme)", Tabor 6/5 (2012): p. 24-7; Holbea, "Raportul”, p. 114-5.

73 This aspect can be noted by reading Father Dumitru Stăniloae's Prologue from his Dogmatics, see idem, Teologia Dogmatică Ortodoxă (Orthodox Dogmatic Theology), I (Bucureşti: Editura Institutului Biblice şi de Misiune al Bisericii Ortodoxe, 1978), p. 5-6. Yet, a general reference to Father Stăniloae's entire work highlights his perception of the patristic character of theology, which indicates its dynamism, a fact emerging as well from his vision on the Philokalia, which he considerably enriched compared to the Greek original, going over the limits of the classical division of the patristic period, precisely because it represents the endless spiritual reality open to every believer regardless of the epoch he lives in. Thus, there is discussion about the Orthodox patristic theology of the $20^{\text {th }}$ century, and Father Stăniloae, combining preoccupations of Dogmatics, Liturgical Theology, Patrology and Patristics, is considered, properly, also the greatest Romanian patrologist (Marinescu, "Patrologia şi studiile de specialitate", p. 316-note 22, 317).

${ }^{74}$ See Marinescu, "Ortodoxie şi ortopraxie, II”, p. 18.

75 Andrew Blane (ed.), Georges Florovsky: Russian Intellectual, Orthodox Churchman (Crestwood, NY: St. Vladimir's Seminary Press, 1993), p. 154; see also Georges H. Williams, "The Neo-Patristic Synthesis of Georges Florovsky", in Andrew Blane (ed.), Georges Florovsky, p. 287-340.

${ }^{76}$ Florovsky, "Patristics and Modern Theology", p. 240; see also Ciprian Iulian Toroczkai, Tradiţia patristică în modernitate. Ecleziologia Părintelui Georges V. Florovsky (1893-1979) în contextul mişcării neopatristice contemporane (The patristic tradition in the modern times. The ecclesiology of Father Georges V. Florovsky (1893-1979) in the context of the contemporary neopatristic movement) (Sibiu: Editura ASTRA Museum, Editura Andreiana, 2012).

${ }^{77}$ See Georges Florovsky, "St. Gregory Palamas and the Tradition of the Fathers", in Bible, Church, Tradition: An Eastern Orthodox View, I, The Collected Works of Georges Florovsky (Belmont: General Editor Richard S. Hauch, 1987), p. 105-20.

${ }^{78}$ Episcopul Hilarion, "Moştenirea patristică”, p. 47.

79 Georges Florovsky, Les voies de théologie russe, traduction et notes J.-L. Palierne (Lausanne: L'Age d'homme, 2001), p. 448. 
7. The term postpastristic can have a chronological meaning, indicating the end of the patristic period, but also a critical one, refering to a relativization, a partial or total contestation, a reconsideration or falling out of the Holy Fathers' theological thinking ${ }^{80}$, which would also denote a normative meaning. For this reason, by the use of this term, the Fathers' spiritual life and holiness, which are the foundation of theologising in the Church, are limited to a certain period, while the divine inspiration of the Holy Fathers' teachings and works, the presence and the work of the Holy Spirit in their life and work are relativized. At the same time, the use of this term leads to a labyrinth of intellectual syllogisms, which saws doubt regarding the Holy Church Fathers' personalities, teachings and writings ${ }^{81}$. The

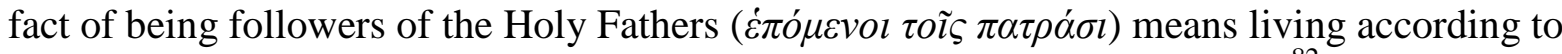
God, which leads to talking with and about Him, namely to true theologizing ${ }^{82}$.

Actually, a division of Patrology based on historical criteria or only depending on the major theological debates or crises cannot be supported ${ }^{83}$, and similarly a separation of the patrological material into early-Christian and patrological or, by extension, into patristic and postpatristic or neopatristic, is neither necessary, nor realistic ${ }^{84}$, because patristic theology represents a unitary and undividable fact. Each type of theology flourished in the bosom of another, so that old [theology] and new theology can only be conventionally distinguished ${ }^{85}$. This affirmation is not unique, because other Orthodox theologians also believe that the patristic period is not over and will continue as long as Christ's Church is present in the world and the Holy Spirit exists in $i t^{86}$. The notion of postpatristic ( manifestation of the Church is a patristic one. Only a scholastic thinking distinguishes between patristic and postpatristic, since patristic theology has always had as its fundamental coordinate "modernity" or "the contemporary man", even though it did not develop a theory of the meeting between the Church and modernity ${ }^{87}$. For this reason, each

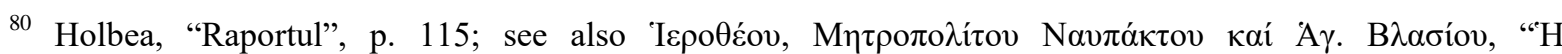

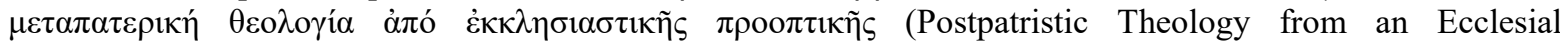

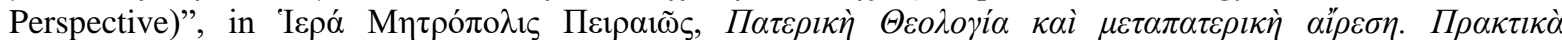

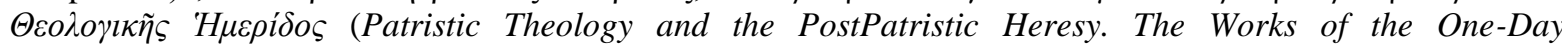

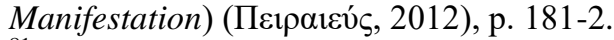

${ }^{81}$ Holbea, "Raportul", p. 116; see also Marinescu, "Patrologia şi studiile de specialitate", p. 360.

${ }^{82}$ Marinescu, "Patrologia şi studiile de specialitate", p. 349.

${ }^{83}$ The patrologist Stylianos Papadopoulos proposes to go over this division and to bring to light the great patristic figures in the context of their epoch, which permits to highlight the great stages of the patristic theology $\left(2^{\text {nd }}\right.$ century: unity of the Church; $3^{\text {rd }}$ century: authenticity of the Church, triadology; $4^{\text {th }}$ century: triadology, pneumatology, christology; $5^{\text {th }}-7^{\text {th }}$ : christology etc.). For this reason, he considers that the criterion of division of Patrology is the knowledge of the theological process of the whole Church, and the theological presentation of a Holy Father shall be better perceived when this is researched in relation to each crisis, having in view, at the same time, also the other efforts of the theologians of the different local Churches. For instance, while Athanasius the Great and the Cappadocian Fathers were fighting against heresies, Evagrius Ponticus was writing his well-known "Chapters on Prayer», a fact showing the multilateral dynamism of the Church during a certain epoch. In this way, by means of the Fathers, we will know the Church, and, by means of the

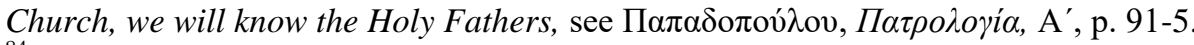

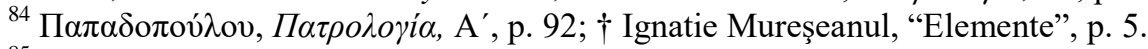

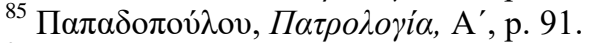

${ }^{86}$ Episcopul Hilarion, "Moştenirea patristică”, p. 26; see also Georges Florovsky, "St. Gregory Palamas”, p. 105-20; Bishop Kallistos Ware, The Orthodox Church (London, 1992), p. 212; Holbea, "Raportul”, p. 115-6.

${ }^{87}$ Marinescu, "Ortodoxie şi ortopraxie, II", p. 27, 28-note 46; Adrian Marinescu, "Ortodoxie şi ortopraxie. Reflecţii privind importanţa, autoritatea şi actualitatea Părinţilor pentru omul contemporan (III) - Cu un studiu de caz privind fenomenologia patristică şi (re)contextualizarea ei în societatea contemporană [Orthodoxy and 
epoch is no less patristic than any other ${ }^{88}$, since the patristic period is an open reality ${ }^{89}$ and $a$ theology of the experience ${ }^{90}$, and man is called to be always patristic, namely to think and act patristically, which means sharing the Holy Fathers' experience and aspirations ${ }^{91}$ in the frame of the Church, where the mystery of the divine iconomy has been lived uninterruptedly, being nothing else but man's salvation in Lord Jesus Christ, God's Son and the world's Saviour ${ }^{92}$. Therefore, on the one hand, if each epoch of the Church has and wins its Fathers, then the patristic work remains forever open (opera aperta), indicating the fact that God's work goes on in the world and in history. On the other hand, the Church has not understood God's work as a limited reality, with beginning and end, but as a dynamic one, to be found both in her entirety and in her parts ${ }^{93}$.

The patristic presence or the patristic feeling has a few features: it protects without oppressing, encourages without flattering, shows mercy without compelling, teaches the Truth without altering $\mathrm{Him}^{94}$, has the capacity to make our faith fully "patristic" and to present it in a language accessible to the $21^{\text {st }}$ century man ${ }^{95}$. All these are due to the fact that the meeting with the Fathers is transforming and invigorating, dynamizing and vivifying for man's life ${ }^{96}$. Based on this experience, Father Dumitru Stăniloae states that there is organic unity between patristic thinking and the thinking having to give an answer to today's problems. Indeed, the Fathers' thinking is immortal ${ }^{97}$ and forever actual, just as their presence in the Church is permanent, since the one, holy, catholic and apostolic Church advances in history by her Saints' steps.

Orthopraxy. Reflections on the Fathers' importance, authority and topicality for the contemporary man (III) With a case study on the patristic phenomenology and its (re)contextualization in the contemporary society]", Tabor 7/6 (2013): p. 40.

${ }^{88}$ Episcopul Hilarion, "Moştenirea patristică”, p. 26.

${ }^{89}$ Marinescu, "Ortodoxie şi ortopraxie, I", p. 18, note 17.

${ }^{90}$ Holbea, "Raportul", p. 127.

${ }^{91}$ Episcopul Hilarion, "Moştenirea patristică”, p. 25; Marinescu, "Ortodoxie şi ortopraxie, I”, p. 28.

92 Dumitru Stăniloae, "Câteva trăsături caracteristice ale Ortodoxiei» (Several characteristic features of the Orthodoxy)", Mitropolia Olteniei 22/7-8 (1970): p. 732; Holbea, "Raportul”, p. 127.

93 Adrian Marinescu, "Criteriile şi fundamentele patristice ale teologiei, elemente structurale ale teologiei ortodoxe dintotdeauna şi premize ale rezolvării problematicii teologice de astăzi (The patristic criteria and fundaments of theology, structural elements of the Orthodox theology since always and premises for solving today's theological problems) (II)", Studii Teologice 9/3 (2013): p. 25, note 35.

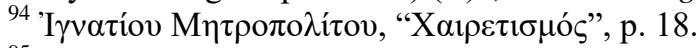

95 Episcopul Hilarion, "Moştenirea patristică”, p. 25.

${ }^{96}$ Marinescu, "Criteriile (I)", p. 286.

97 Jürgen Henkel, “Teologia conform tradiţiei Părinţilor Bisericii: dogmatica şi metoda teologică a Părintelui Stăniloae (Theology according to the Church Fathers's tradition: Father Stăniloae's dogmatics and theological method)", in IPS Laurenţiu Streza, J. Henkel, Gh. F. Anghelescu (editors), Dumitru Stăniloae (1903-1993). Teologie românească de dimensiune europeană [Dumitru Stăniloae (1903-1993). Romanian Theology of European Dimension] (Sibiu: Editura Schiller, 2007), p. 258. 


\section{BIBLIOGRAPHY:}

[1] Alfeyev, Episcopul Hilarion, "Moștenirea patristică și modernitatea", traducere de Ștefan Toma, Revista teologică 17 (89)/2 (2007).

[2] Băjău, Constantin I. Patrologie şi literatură post-patristică (Craiova: Editura Universitaria, 2013).

[3] Idem, Patrologie (Craiova: Tipografia Universității, ${ }^{3} 2002$ ).

[4] Blane, Andrew (ed.), Georges Florovsky: Russian Intellectual, Orthodox Churchman (Crestwood, NY: St. Vladimir's Seminary Press, 1993).

[5] Bota, Ioan M., Patrologia (Cluj-Napoca: Editura Viața Creștină, $\left.{ }^{2} 2002\right)$.

[6] Calvo, Juan José Ayan, "Mâna creatoare a lui Dumnezeu", in Cristian Bădiliță, Știință. Dragoste. Credință. Convorbiri cu patrologi europeni (Col. „Știință și Religie” (București: Editura Curtea Veche, 2008).

[7] Cayré, F., Patrologie et Histoire de la Théologie, Livres III et IV (Paris, Tournai, Rome: Desclée et Cie, Editeurs Pontificaux, ${ }^{2} 1933$ ).

[8] Idem, Précis de Patrologie et d'Histoire de la Théologie, Livres I et II (Paris, Tournai, Rome: Desclée et Cie, Editeurs Pontificaux, ${ }^{2} 1931$ ).

[9] Chițescu, N., "Ființa dogmei", Studii Teologice 5/3-4 (1953).

[10] Coman, Ioan G., "Sfânta Tradiție în lumina Sfinților Părințị”, Ortodoxia 8/2 (1956).

[11]Idem, Patrologie (București: Editura Institutului Biblic și de Misiune Ortodoxă, 1956).

[12] Idem, Patrologie, vol. I (București: Editura Institutului Biblic și de Misiune al Bisericii Ortodoxe Române, 1984).

[13]Croitoru, Ion Marian, "Problematizări privind creșterea învățăturii dogmatice în lumea ortodoxă contemporană", in Universitatea Ovidius, Facultatea de Teologie Sfântul Andrei, Tradiție și continuitate în teologia tomitană. Două decenii de invățământ teologic universitar la Constanța. 1992-2012. Simpozion Internațional (2012, Constanța) (Constanța: Editura Arhiepiscopiei Tomisului, 2012/2013).

[14] Idem, "The Growth of the Dogmatic Teaching in the Contemporary Orthodox World. Questions and Problematizations", International Journal of Orthodox Theology 6/1 (2015).

[15]Deicha, Sophie, "Impulsion donnée par le Métropolite Philarète de Moscou (1782-1826) aux études patristiques en Russie au XIX ${ }^{\mathrm{e}}$ siècle", Studia Patristica XXIII (1993).

[16] Florovsky, Georges, "Patristics and Modern Theology", in Procès-verbaux du Premier Congrès de Théologie Orthodoxe à Athènes, 29 novembre-6 décembre 1936, publiés par les soins du Président Prof. Hamilcas S. Alivisatos (Athènes: Editions Pyrsos, 1939).

[17] Idem, "Westliche Einflüsse in der russischen Theologie", in Procès-verbaux du Premier Congrès.

[18] Idem, "St. Gregory Palamas and the Tradition of the Fathers", in Bible, Church, Tradition: An Eastern Orthodox View, I, The Collected Works of Georges Florovsky (Belmont: General Editor Richard S. Hauch, 1987).

[19] Idem, Les voies de théologie russe, traduction et notes J.-L. Palierne (Lausanne : L'Age d'homme, 2001).

[20]Fouilloux, Etienne, La collection « Sources chrétiennes » : éditer les Pères de l'Eglise au XX siècle (Paris : Cerf, 1995).

[21] Idem, Les Catholiques et l'unité chrétienne : du XIX au XX siècle, itinéraires européens d'expression française (Paris : Le Centurion, 1982).

[22] Gonnet, s.j., Dominique, "La portée œcuménique de Sources Chrétiennes", in Patristique et œecuménisme. Thèmes, contextes, personnages. Colloque international sous le patronage de Mgr Teodosie, Archevêque de Tomis Constanța (Roumanie), 17-20 octobre 2008, éd. Cristian Bădiliță, Collection PONTUS EUXINUS (Paris : Editions Bauchesne, Târgu Lăpuș: Editura Galaxia Gutenberg, 2010).

[23]Henkel, Jürgen, "Teologia conform tradiției Părinților Bisericii: dogmatica și metoda teologică a Părintelui Stăniloae”, in IPS Laurențiu Streza, J. Henkel, Gh. F. Anghelescu (editori), Dumitru Stăniloae (1903-1993). Teologie românească de dimensiune europeană (Sibiu: Editura Schiller, 2007).

[24] Holbea, Gheorghe, "Raportul dintre teologia patristică și teologia post-patristică", Ortodoxia 4/2 (2012).

[25] Ignatie Mureșeanul, "Elemente de isagogie în studiul patristic", http://comptepv.typepad.fr/files/elemente-de-isagogie-patristica.pdf (accesat la 25 iulie, 2015). 
[26] Iordăchescu, Cicerone, Istoria vechii literaturi creștine (Primele trei veacuri până la 325), vol. I (Chișinău: Tipografia Țerek \& Caminschi, 1934; Iași: Editura Moldova, $\left.{ }^{2} 1996\right)$.

[27] Idem, Istoria vechii literaturi creștine (Epoca de la 461 la 636/750), vol. III (Chișinău: Tipografia Țerek \& Caminschi, 1940; Iași: Editura Moldova, $\left.{ }^{2} 1996\right)$.

[28] Marinescu, Adrian, "Criteriile și fundamentele patristice ale teologiei, elemente structurale ale teologiei ortodoxe dintotdeauna și premize ale rezolvării problematicii teologice de astăzi (I)", Studii Teologice 9/2 (2013); (II), Studii Teologice 9/3 (2013).

[29] Idem, "Ortodoxie și ortopraxie. Reflecții privind importanța, autoritatea și actualitatea Părinților pentru omul contemporan (I)", Tabor 5/12 (2012); “(II) - Cu un studiu de caz privind fenomenologia patristică și (re)contextualizarea ei în societatea contemporană”, Tabor 6/7 (2012); “(III) - Cu un studiu de caz privind fenomenologia patristică și (re)contextualizarea ei în societatea contemporană ", Tabor 7/6 (2013).

[30] Idem, "Patrologia și studiile de specialitate în cadrul Ortodoxiei din secolul al XX-lea și începutul secolului al XXI-lea. Școli și direcții de cercetare", in Teologia ortodoxă în secolul al XX-lea și la inceputul secolului al XXI-lea, coord. Pr. prof. dr. Viorel Ioniță (București: Editura Basilica a Patriarhiei Române, 2011).

[31] Moga, Ioan, "Despre maladiile teologiei. Marginalii la o temă actuală", Tabor 6/5 (2012).

[32] Mondésert, Claude, "La collection « Sources Chrétiennes »", Byzantion XX (1950).

[33] Moreschini, Claudio / Norelli, Enrico, Istoria literaturii creștine vechi grecești și latine, II/1, De la Conciliul de la Niceea la începuturile Evului Mediu, traducere din italiană de Elena Caraboi, Doina Cernica, Emanuela Stoleriu și Dana Zămosteanu (Iași: Editura Polirom, 2013).

[34] Patrologia. Seria graeca (161 vol., Paris, 1857-1866).

[35] Patrologia. Seria latina (221 vol., Paris, 1841-1864).

[36] Pătrașcu, Damian Gheorghe, Patrologie și Patristică. Secolele I-IV, vol. I (Roman: Editura Serafica, 2007).

[37]Pelikan, Jaroslav, Tradiția creștină. O istorie a dezvoltării doctrinei. I. Nașterea tradiției universale (100-600), traducere din limba engleză de Silvia Palade (Iași: Editura Polirom, 2004).

[38] Stăniloae, Dumitru, "Câteva trăsături caracteristice ale Ortodoxiei”, Mitropolia Olteniei 22/7-8 (1970).

[39] Idem, Teologia Dogmatică Ortodoxă, I (București: Editura Institutului Biblice şi de Misiune al Bisericii Ortodoxe, 1978).

[40] Șesan, M., "Despre încheierea epocii patristice", Mitropolia Moldovei și Sucevei 53/5-6 (1967).

[41] Toroczkai, Ciprian Iulian, Tradiția patristică in modernitate. Ecleziologia Părintelui Georges V. Florovsky (1893-1979) în contextul mișcării neopatristice contemporane (Sibiu: Editura ASTRA Museum, Editura Andreiana, 2012).

[42] Turcescu, Lucian, «"Person" versus "Individual", and Other Modern Misreadings of Gregory of Nyssa», in Cristian Bădiliță, Charles Kannengiesser (éd.), Les Pères de l'Eglise dans le monde d'aujourd'hui. Actes du colloque international organisé par le New Europe College en collaboration avec la Ludwig Boltzmann Gesellschaft (Bucarest, 7-8 octobre 2004) (Paris: Beauchesne, București: Curtea Veche, 2006).

[43] Idem, Gregory of Nyssa and the Concept of Divine Persons (New York: Oxford University Press, 2005).

[44] Voicu, Constantin / Colda, Lucian-Dumitru, Patrologie, vol. I-II (București: Editura Basilica a Patriarhiei Române, 2009), vol. III (București: Editura Basilica a Patriarhiei Române, 2010).

[45] Idem, Patrologie, I (București: Editura Basilica a Patriarhiei Române, 2009).

[46] Ware, Bishop Kallistos, The Orthodox Church (London, 1992).

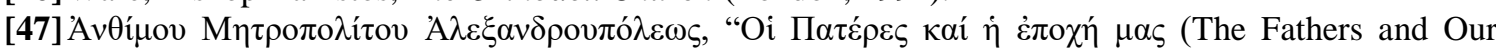

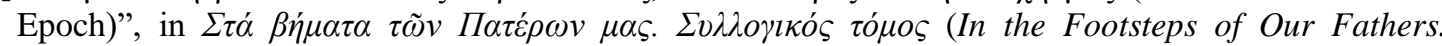

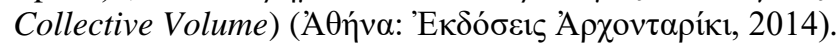

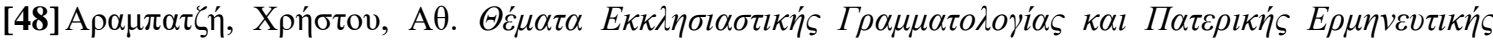

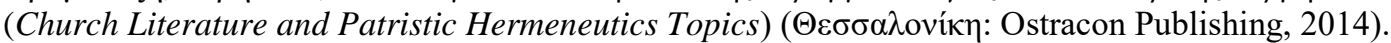

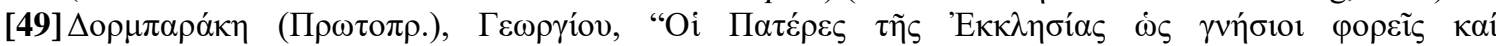

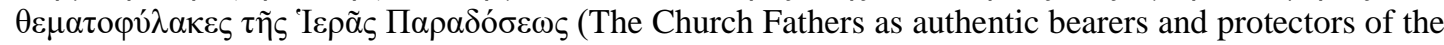

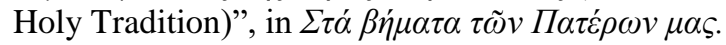

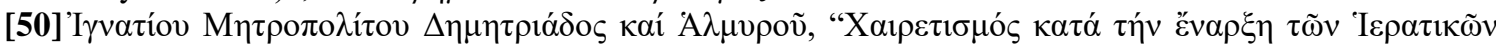

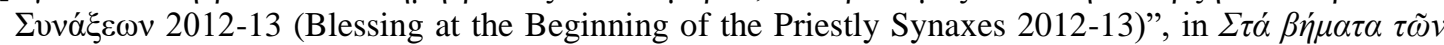

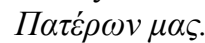




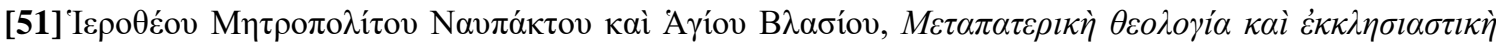

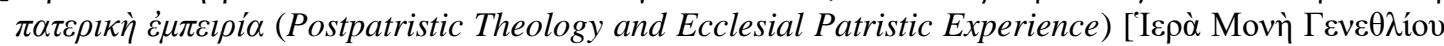

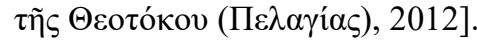

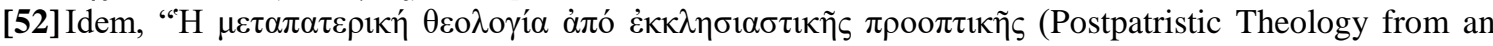

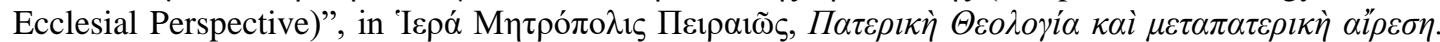

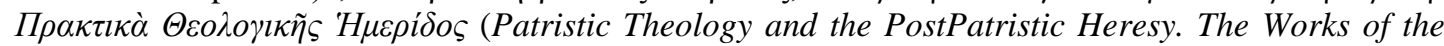
One-Day Manifestation) (Пєıраıєús, 2012).

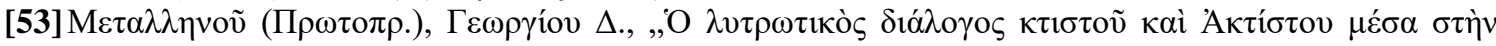

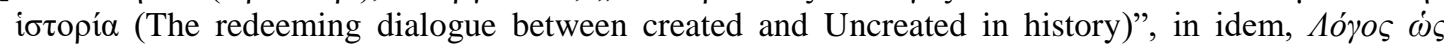

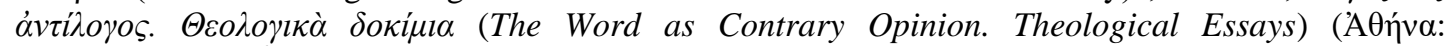

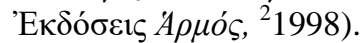

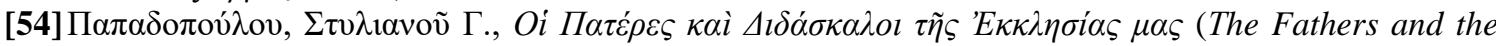

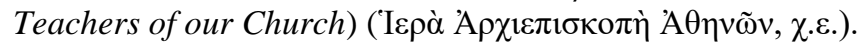

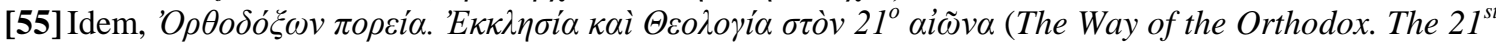

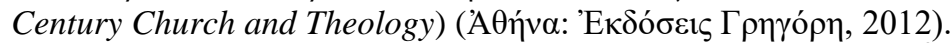

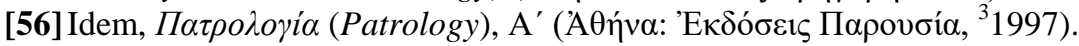

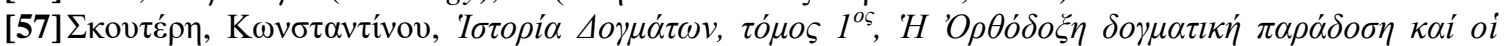
$\pi \alpha \rho \alpha \chi \alpha \rho \alpha ́ \xi \varepsilon l \varsigma \tau \eta \varsigma ~ \kappa \alpha \tau \alpha \dot{~} \tau o v ́ \varsigma \tau \rho \varepsilon \tilde{\iota} \varsigma \pi \rho \omega ́ \tau o v \varsigma \alpha i \tilde{\omega} v \varepsilon \varsigma$ (History of Dogmas, vol. I, The Orthodox Dogmatic Tradition and Its Falsifications during the First Three Christian Centuries) ('A $\theta \dot{\eta} v \alpha, 1998)$.

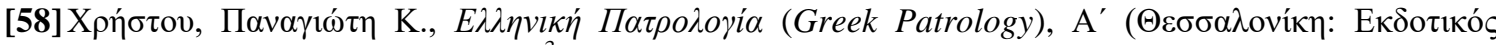

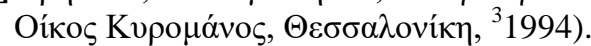

